\title{
Perception of Goat Milk Products
}

\section{Csapo Zsolt ${ }^{1}$, Pentek Adam ${ }^{2}$ and Csapone Risko Tunde ${ }^{3^{*}}$}

${ }^{1}$ University of Debrecen, Faculty of Economics and Business, Department of Enterprise Development, Böszörményi Str. 138, 4032 Debrecen, Hungary

${ }^{2}$ University of Debrecen, Faculty of Economics and Business, Department of Agricultural Informatics, Böszörményi Str. 138, 4032 Debrecen, Hungary

${ }^{3}$ University of Debrecen, Faculty of Economics and Business, Department of World Economy and International Relations, Böszörményi Str. 138, 4032 Debrecen, Hungary

*Corresponding author: risko.tunde@econ.unideb.hu (ORCID ID: 0000-0001-7704-1159)

\begin{abstract}
The unique characteristics of goat milk have been rather well studied as regards its nutritional value and health effects. It has been documented as an excellent food source. It has beneficial effects for health maintenance, physiological functions, as well as in the nutrition of children and elderly people. The medicinal value of goat milk has been documented in Nepalese Ayurveda and Indian Ayurveda. Goat milk was recommended as an affective dietary item for patients suffering from certain diseases. In spite of its health benefits, goat milk and goat milk products are not among the widely consumed dairy products in Hungary. Hungarian consumers prefer cow milk and cow milk products over goat milk and goat milk products. The most preferred goat milk products are cheese and cottage cheese. The main reasons for refusing goat milk products are their taste and smell, availability and affordability of these products. The objective of the present research is to investigate the perceived characteristics of goat milk products through blind testing in comparison with cow and sheep milk products (cheese, cottage cheese, plain and fruity yogurt). The research revealed that the perception of goat cheese and cottage regarding its outlook, smell, fatness, taste and colour is rather similar to the tested cow and sheep cheese and cottage cheese. The perception (homogeneity, smell, density, taste, colour, creaminess) of cow and goat plain and fruity yogurts are also rather similar. Considerable negative perception towards the tested goat milk products have not been revealed.
\end{abstract}

\section{Highlights}

( The perception of goat milk products through blind testing was similar to the tested cow and sheep milk products.

Keywords: goat milk products, health, marketing

India has the largest livestock population in the world. India stands second in goat population (140 million). In India Rajasthan stands first in goat population (21,50 million), followed by West Bengal (15,96 million), and Utter Pradesh (14,79 million) (Baldodiya and Sharma, 2018). The countries with the largest dairy goat populations are Bangladesh, India and Mali. Major goat milk producers are India, Bangladesh and Pakistan. The average milk yields of goats vary significantly among major milk producing countries (FAO, 2018). India is the world's largest producer of goat milk, with an annual production of over 5 million metric tons. Goat rearing is popular in India because of the cultural implications and taboos imposed on the cow. The number of goats in India makes almost $25 \%$ of the total livestock (worldatlas, 2017).

How to cite this article: Csapo, Zs., Pentek, A. and Csapone, R.T. (2019). Perception of goat milk products. Economic Affairs, 64(4): 679-688. 
Until the end of the 1990s goat breeding in Hungary was relatively unimportant. However, new demand for so-called alternative products meeting the requirements of healthy nutritional trends began to appear in the country. Initially, this new demand was satisfied with imported products, since the national goat population and goat milk products could not compete with imported products (Marticsek et al. 1999). Due to many efforts, today, local goat milk and goat milk products can meet any and all market requirements (Szigeti, 2004).

The number of individuals and companies keeping goats as a livelihood generated income or business reasons is probably a few hundred in Hungary. The number of farmers keeping some goats as a hobby or providing the family with goat milk is probably a few thousand (Kukovics, 2007a). There are around 3-5.000 goat keepers in Hungary and less than $80 \%$ keeps less than 10 goats. The breeds mainly belongs to Hungarian breeds, but $10 \%$ stem from imported breeds, such as Saanen, Alpine, Boer or Anglo-Nubian (Kukovics, 2008a). Many poor people keep goats in Hungary, in mainly underprivileged regions (Kukovics, 2007b). The production level (and number of goats), as well as keeping conditions are lagging behind the data for France, Spain, Italy, Greece and the Netherlands (Kukovics, 2008b). Production level of the sector is weak and has been struggling with several problems for many years. The number of goat breeders and goats continuously fluctuates and the data are patchy. The number of goats was 65,3 thousand in 2018 in Hungary (KSH, 2019). With the growing importance of healthy nutrition and lifestyle, growing demand is expected for goat milk and goat milk products that could contribute to the development of the goat sector (Kocsisné Gráf, 2011).

Although goat breeding has seemed to be more organized since 2009, the number of goats in nucleus herds was still much lower in 2013 than before 2008. Most goats still do not belong to any specific breed, and most herds and animals are not registered or individually identified. The quality of breeding work should be improved and product marketing has to be developed to ensure a brighter future for goat farmers in Hungary (Kukovics and Baranyai, 2016).

The main product of the goat sector is milk in Hungary. The estimated goat milk production is around 3-5 million litre per year, but only 0,6 million litres are manufactured by milk factories. The main income of milk producing farmers comes from milk and manufactured goat milk products. It is common in the sector that goat breeders sell the produced goat milk and self-made goat milk productsdirectly (Hungarian Chamber of Agriculture, 2017). The goat milk production was 3,5 million litre in 2017 in Hungary (KSH, 2018).

Goat milk is processed by only a few small or larger dairy plants in Hungary. Processing plants have to overcome several difficulties, such as the dispersion of breeding farms, and competition with products imported from other EU and neighbouring countries (Slovakia and Romania), which are readily accepted by Hungarian consumers (Seregi and Kovács, 2016).

The use of goat milk as an excellent food source is undeniable. It has beneficial effects for health maintenance, physiological functions, in the nutrition of children and elderly people (Billion, 2003; Albenzo et al. 2006; Domonkos and Geiner, 2009; Yangilar, 2013; Csapó and Csapóné, 2019).

Fenyvessy (2009) reports that goat milk and its role in human nutrition came into fashion in the Hungarian press only in recent years. The studied papers emphasise the role of goat milk and goat dairy products in preserving health, although the statements are sometimes contradictory.

Szigeti (2004) and Szigeti et al. (2005) report on the results of an empirical research carried out in Hungary. Only a small ratio of respondents reported only very rarely buying and consuming goat milk products. The most often purchased product was cheese. The main reason for refusing goat milk products were: they did not like the taste of goat milk products, they did not even know these products, these products are not easy to find and buy. The main reasons for buying these products are: healthiness, taste and quality. The respondents were concerned that goat dairy products were expensive. The research revealed that respondents were not familiar with the available brands and nutritional benefits of goat dairy products. Another empirical research (Szigeti et al. 2014) revealed that the opinion of Hungarian respondents had not changed much since the time of the previous studies. Goat dairy products are still rarely consumed. The most preferred products are cheeses, followed by cottage cheese. 
Since there is a considerable prejudice against goat milk products in Hungary, like having a special goaty flavour and smell, the objectives of the study is to investigate the perceived characteristics of goat milk products through blind testingin comparison with cow and sheep milk products (cheese, cottage cheese, plain and fruity yogurt). During blind testing participants do not know the origin of the tasted products(cow, sheep or goat milk product), they see a number only on each tested item. During blind testing participants are not affected by the brand or design of the tested products, since these characteristics are not visible, the tested items are neutral. We consider this research method appropriate since blind testing aims to assess a product on its intrinsic merits by hiding any reference to the wider brand or any other product information. It is a proper research method toobtain information about customers' perceptions and preferences on the goods. This avoids results being influenced by any halo effect or negative associations set up by previous experiences, this means that any bias, preconceived ideas about a particular brand or food, is eliminated. The idea is to focus on the intrinsic product characteristics only. Once knowing the perceptions and preferences of our respondents after the blind testing, we are going to complete this research with an online survey investigating the informedness of respondents on goat milk products (their health benefits, availability, and brands) and consumption of such products and frequency of consumption, or refusal of these products with reasoning, affordability of these products, prejudices, etc. Further planned ways of our research is to map the availability, price and origin of goat milk products (Hungarian and imported) in Debrecen, Hungary and to study the economic aspects of goat milk production, as well as the practices and costs of manufacturing goat milk products. Sunil et al. (2016) also emphasises that the cost of milk production is an important tool for the evaluation of economics of dairy farms at producers' level. After conducting these surveys and analyses we are aiming to contribute with recommendations to the marketing and trade of goat milk products in Hungary.

\section{MATERIAL AND METHODS}

The empirical research was conducted in the autumn 2018 and the beginning of 2019 with the involvement of 202 respondents in Debrecen, Hungary. The empirical research involved blind testing of cow, goat and sheep milk products, such as cheese, cottage cheese and yogurts (plain and fruity). All the tested milk products have been purchased directly from local producers, so they were quality handmade products. Respondents did not know what kind of cheese, cottage cheese, plain and fruity yogurt they tested. The tested products were numbered. During the blind testing respondents were asked to fill in a questionnaire for each tested milk product.

- In case of cheese, they tested cow, sheep and goat cheese and assessed them using one form. Cheeses were numbered (No. 1: cheese made from cow milk, No. 2: cheese made from sheep milk and No. 3: cheese made from goat milk). Characteristics (outlook, smell, taste, fatness and colour) of the 3 cheeses were tested by the respondents using Likert scale 1-10 (1 meaning the worst and 10 meaning the best). The affordable price of 100 gr of the 3 different cheese was also asked, as well as the preferred way of consumption.

- In case of cottage cheese, they tested cow, sheep and goat cottage cheese and assessed them using one form. The cottage cheeses were numbered (No.1: made from cow milk, No.2: made from sheep milk and No.3: made from goat milk). Characteristics (outlook, smell, taste, fatness and colour) of the 3 cottage cheeses were tested by the respondents using Likert scale 1-10 ( 1 meaning the worst and 10 meaning the best). The affordable price of $250 \mathrm{gr}$ of the 3 different cottage cheese was also asked, as well as the preferred way of consumption.

- In case of plain yogurts, they tested cow and goat plain yogurt and assessed them using one form. Characteristics (homogeneity, smell, density, taste, creaminess, and colour) of the two yogurt samples were tested by the respondents using Likert scale 1-10 (1 meaning the worst and 10 meaning the best). The affordable price of a cup ( 150 gr) of the two different yogurts was also asked. The preferred ways of consumption was asked (with fruit, with bakery product, to cook with, to salads, with honey) using Likert scale 1-5 (1 meaning the least and 5 meaning the most preferred way). It was 
also asked which fruits they would add to the certain plain yogurts? They had to list max. 3 fruits to each yogurt.

- In case of fruity yogurts, they tested cow and goat fruity yogurt and assessed them using one form. Characteristics (homogeneity, smell, density, taste, creaminess, and colour) of the two yogurt samples were tested by the respondents using Likert scale 1-10 (1 meaning the worst and 10 meaning the best). The affordable price of a cup (150 gr) of the two different fruity yogurts was also asked.

Data were processed in SPSS. Regarding statistical methods, mean, median, standard deviation coefficient $(\mathrm{H})$ and coefficient of variation $(\mathrm{H} 2)$ were calculated.

Distribution of the sample is shown in Table 1. It shows that the proportion of female to male in the sample is almost two times higher. Regarding the age distribution of the sample, the proportion of age group of 15-24 years is the highest. The place of residence is mainly city of county and town $(36,6 \%$ and 50,5\% respectively). The highest level of school respondents have completed is secondary school $(59 \%)$. The perceived income level of respondents is average for most respondents $(68,3 \%)$.

Table 1: Distribution of the sample $(\mathrm{n}=202)$

\begin{tabular}{ll}
\hline Gender & \% \\
\hline Male & 34 \\
Female & 66 \\
\hline Age groups & \\
\hline $15-24$ years & 33 \\
25-35 years & 15 \\
36-45 years & 24 \\
$46-54$ years & 14 \\
55-64 years & 6 \\
65- years & 8 \\
\hline
\end{tabular}

\begin{tabular}{ll}
\hline Place of residence & \\
\hline Capital city & 1 \\
City of county & 36,6 \\
Town & 50,5 \\
Village & 8,9 \\
\hline Educational level & \\
\hline Elementary school & 13 \\
Secondary school & 59 \\
University degree & 28 \\
\hline
\end{tabular}

\begin{tabular}{ll}
\hline Perceived income level & \\
\hline Significantly under the average & 3 \\
Under the average & 17,8 \\
Average & 68,3 \\
Above the average & 5 \\
Significantly above the average & 5,9 \\
\hline
\end{tabular}

Source: Own research, 2018, 2019.

\section{RESULTS AND DISCUSSION}

\section{Cheese}

Respondents had to assess five characteristics of the three tested cheeses using Likert scale 1-10 (1 is the worst and 10 is the best). Assessment of the three cheeses can be seen in Tables 2-6.

Table 2: Outlook of the tested cheeses

\begin{tabular}{llll}
\hline \multirow{2}{*}{ Value } & \multicolumn{3}{c}{ Outlook } \\
\cline { 2 - 4 } & Cow & Sheep & Goat \\
\hline Mean & 8,39 & 8,32 & 8,12 \\
Median & 9,00 & 9,00 & 8,00 \\
Standard deviation & 1,703 & 1,837 & 1,838 \\
\hline
\end{tabular}

Source: Own research, 2018, 2019.

Table 3: Smell of the tested cheeses

\begin{tabular}{llll}
\hline \multirow{2}{*}{ Value } & \multicolumn{2}{l}{ Smell } & \\
\cline { 2 - 4 } & Cow & Sheep & Goat \\
\hline Mean & 7,99 & 8,27 & 8,03 \\
Median & 8,00 & 8,00 & 8,00 \\
Standard deviation & 1,938 & 1,679 & 1,923 \\
\hline
\end{tabular}

Source: Own research, 2018, 2019.

Table 4: Fatness of the tested cheeses

\begin{tabular}{llll}
\hline \multirow{2}{*}{ Value } & \multicolumn{3}{c}{ Fatness } \\
\cline { 2 - 4 } & Cow & Sheep & Goat \\
\hline Mean & 8,28 & 7,00 & 7,89 \\
Median & 8,00 & 7,00 & 8,00 \\
Standard deviation & 1,578 & 2,021 & 1,943 \\
\hline
\end{tabular}

Source: Own research, 2018, 2019.

Table 5: Taste of the tested cheeses

\begin{tabular}{llll}
\hline \multirow{2}{*}{ Value } & \multicolumn{3}{c}{ Taste } \\
\cline { 2 - 4 } & Cow & Sheep & Goat \\
\hline Mean & 8,04 & 7,68 & 7,46 \\
Median & 8,00 & 7,00 & 8,00 \\
Standard deviation & 2,030 & 2,218 & 2,422 \\
\hline
\end{tabular}

Source: Own research, 2018, 2019. 
Table 6: Colour of the tested cheeses

\begin{tabular}{llll}
\hline \multirow{2}{*}{ Value } & \multicolumn{3}{c}{ Colour } \\
\cline { 2 - 4 } & Cow & Sheep & Goat \\
\hline Mean & 8,55 & 8,21 & 8,24 \\
Median & 9,00 & 8,00 & 9,00 \\
Standard deviation & 1,911 & 1,802 & 1,910 \\
\hline
\end{tabular}

Source: Own research, 2018, 2019.

Results of the empirical research show in all cases, that the mean is relatively high, around 8 in case of each characteristics with only slight differences. The medianis the value separating the higher half from the lower half of a data sample. In case of our research, the median is around the mean. Regarding standard deviation, a low standard deviation indicates that the data points tend to be close to the mean of the set, while a high standard deviation indicates that the data points are spread out over a wider range of values. The standard deviation shows in all three cases that our data are not homogenous. The results show that the perceived characteristics of the tested cheese were rather similar for respondents, however the data were heterogeneous.

Regarding the question: 'How much would you pay for 100 gr cheese?' The mean was 0,65 USD for cheese No. 1, 0,78 USD for cheese No. 2 and 0,82 USD for cheese No. 3. It shows, that respondents would pay the highest amount for goat cheese. We can suppose that this higher price is connected to the perceived higher quality.

We asked our respondents how they would eat the tested cheese. They had to consider the following options: alone, grilled, use as a kitchen row material. They had to rate these options on a scale 1-3, where 3: the most and 1: the least preferred way of consumption. For the cow cheese we can state that the preferred way of consumption is 'alone' (mean $=2,40)$, followed by as a 'kitchen row material' (mean=2,35), while the 'grilled' version $($ mean $=2,09)$ is the least preferred way of consumption. For the sheep cheese we got the same order, but the means for the first two versions (mean=2,16 and 2,14 respectively) were much lower. In case of the goat cheese the most preferred way of consumption is as a 'kitchen row material' (mean=2,30) followed by 'alone' (mean=2,24) and the 'grilled' version is the least preferred way of consumption (mean=2,07).
It can be stated, that in all cases the mean and median are quite close to each other. The standard deviation is low, thus the data are homogenous. It can be stated, that respondents would like to eat all the three cheeses in the same way.

The coefficient of variation (H2) calculated by the division of the external variance and the total variance, shows how the 'income' category determines the amount to be paid for cheese. This value is $0,493 \%$. The standard deviation coefficient $(\mathrm{H})$ defines the strengthness of the relationship between the above mentioned two criteria. It is $0,07 \%$. This means that the amount to be paid for the cheese does not depend on the income level of respondents.

The coefficient of variation ( $\mathrm{H} 2)$ calculated by the division of the external variance and the total variance, shows how the 'age' category determines the amount to be paid for cheese. This value is $3,289 \%$. The standard deviation coefficient $(\mathrm{H})$ defines the strengthness of the relationship between the above mentioned two criteria. It is $0,18 \%$. This means that the amount to be paid for the cheese does not depend on the age of respondents.

\section{Cottage cheese}

Respondents had to assess five characteristics of the three tested cottage cheeses using Likert scale 1-10 ( 1 is the worst and 10 is the best). Assessment of the three cheeses can be seen in Tables 7-11.

Table 7: Outlook of the tested cottage cheeses

\begin{tabular}{llll}
\hline \multirow{2}{*}{ Value } & \multicolumn{3}{c}{ Outlook } \\
\cline { 2 - 4 } & Cow & Sheep & Goat \\
\hline Max. & 2,0 & 1,0 & 2,0 \\
Min. & 10,0 & 10,0 & 10,0 \\
Mean & 8,1 & 7,8 & 7,8 \\
Standard deviation & 1,9 & 2,3 & 1,9 \\
\hline
\end{tabular}

Source: Own research, 2018, 2019

Table 8: Smell of the tested cottage cheeses

\begin{tabular}{llll}
\hline \multirow{2}{*}{ Value } & \multicolumn{3}{c}{ Smell } \\
\cline { 2 - 4 } & Cow & Sheep & Goat \\
\hline Max. & 2,0 & 2,0 & 1,0 \\
Min. & 10,0 & 10,0 & 10,0 \\
Mean & 7,5 & 8,0 & 7,1 \\
Standard deviation & 2,2 & 2,0 & 2,3 \\
\hline
\end{tabular}

Source: Own research, 2018, 2019. 
Table 9: Taste of the tested cottage cheeses

\begin{tabular}{llll}
\hline \multirow{2}{*}{ Value } & \multicolumn{3}{c}{ Taste } \\
\cline { 2 - 4 } & Cow & Sheep & Goat \\
\hline Max. & 1,0 & 1,0 & 1,0 \\
Min. & 10,0 & 10,0 & 10,0 \\
Mean & 7,3 & 7,7 & 6,5 \\
Standard deviation & 2,6 & 2,3 & 2,6 \\
\hline
\end{tabular}

Source: Own research, 2018, 2019.

Table 10: Fatness of the tested cottage cheeses

\begin{tabular}{llll}
\hline \multirow{2}{*}{ Value } & \multicolumn{3}{c}{ Fatness } \\
\cline { 2 - 4 } & Cow & Sheep & Goat \\
\hline Max. & 2,0 & 2,0 & 2,0 \\
Min. & 10,0 & 10,0 & 10,0 \\
Mean & 7,7 & 7,2 & 7,4 \\
Standard deviation & 2,0 & 2,2 & 2,1 \\
\hline
\end{tabular}

Source: Own research, 2018, 2019.

Table 11: Colour of the tested cottage cheeses

\begin{tabular}{llll}
\hline \multirow{2}{*}{ Value } & \multicolumn{3}{c}{ Colour } \\
\cline { 2 - 4 } & Cow & Sheep & Goat \\
\hline Max. & 2,0 & 2,0 & 2,0 \\
Min. & 10,0 & 10,0 & 10,0 \\
Mean & 8,5 & 8,2 & 8,3 \\
Standard deviation & 1,9 & 2,1 & 1,8 \\
\hline
\end{tabular}

Source: Own research, 2018, 2019.

Results of the empirical research show, that the means are the highest for cottage cheese No. 1 (between 7,3-8,5). The means are relatively lower in case of cottage cheese No. $2(7,2-8,2)$ and the lowest in case of cottage cheese No. $3(6,5-8,3)$. It might reflect that cottage cheese made from cow milk is the most commonly consumed in Hungary. Cottage cheese made from sheep and goat milk are not so widely consumed. Regarding standard deviation, a low standard deviation indicates that the data points tend to be close to the mean of the set, while a high standard deviation indicates that the data points are spread out over a wider range of values. The standard deviation shows in all three cases that our data are not homogenous. The results show that the perceived characteristics of the tested cottage cheese were more or less similar for respondents, however the data were heterogeneous.

We asked our respondents how much they would pay for 250 gr cottage cheese? The mean was 0,98 USD for cottage cheese No. 1, 1,13USD for cottage cheese No. 2 and 0,95 USD for cottage cheese No.
3. It shows, that respondents would pay the highest amount for the cottage cheese made from sheep milk. They would be willing to pay the lowest price for the cottage cheese made from goat milk. It could be reasoned with the fact that goat milk products are not easy to buy, their price is high and they are not widely known and consumed in Hungary.

We asked our respondents how they would eat the tested cheese. There were two options: sweet (like vanilla flavoured creamy cottage cheese, cottage cheese dumplings, cottage cheese donut, etc.) or salty (pasta with cottage cheese, cottage cheese spread, etc.). The most preferred way of consumption is sweet for cottage cheese made from cow $(64,9 \%)$ and goat $(52,9 \%)$ milk. Sheep cheese is basically salty, that might be the reason why most respondents would consume it salty $(75,7 \%)$.

\section{Plain yogurt}

Respondents had to evaluate plain yogurts using Likert scale 1-10 (1 meaning the worst and 10 meaning the best). Five different characteristics were evaluated by the respondents like homogeneity, density, creaminess, taste and colour. When tasting the plain yogurts respondents were asked to fill in a questionnaire. Evaluation of plain yoghurt No. 1 can be seen in Table 12 .

Table 12: Assessment of plain yogurt No. 1 (cow milk yogurt) $\mathrm{n}=202$

\begin{tabular}{lllllll}
\hline \multirow{2}{*}{ Value } & \multicolumn{5}{c}{ Characteristics } \\
\cline { 2 - 7 } & $\begin{array}{l}\text { Homo- } \\
\text { geneity }\end{array}$ & Smell & $\begin{array}{l}\text { Den- } \\
\text { sity }\end{array}$ & Taste & $\begin{array}{l}\text { Co- } \\
\text { lour }\end{array}$ & $\begin{array}{l}\text { Cream- } \\
\text { iness }\end{array}$ \\
\hline Mean & 7,66 & 8,06 & 8,30 & 7,78 & 8,57 & 8,03 \\
Median & 8,00 & 8,00 & 9,00 & 8,50 & 9,00 & 9,00 \\
Standard & 2,204 & 2,180 & 1,995 & 2,422 & 1,808 & 1,962 \\
deviation & & & & & & \\
\hline
\end{tabular}

Source: Own research, 2018, 2019.

As regards yogurt No. 1., results of the blind testing (Table 12) show in all cases, that the mean is relatively high, around 8 in case of each characteristics with only slight differences. As regards yogurt No. 2., results of the blind testing (Table 13) show in all cases, that the mean is also relatively high, between 6,33 and 8,42 . The median is the value separating the higher half from the lower half of a data sample. In case of our research, the median is around the mean. Regarding standard 
deviation, a low standard deviation indicates that the data points tend to be close to the mean of the set, while a high standard deviation indicates that the data points are spread out over a wider range of values. The standard deviation shows in all cases that our data are not homogenous. We can state that perception of goat milk plain yogurt was only slightly worse than the perception of cow milk plain yogurt. The perceived characteristics of the goat and cow milk yogurt were just slightly different by the respondents. Since in Hungary cow milk yogurts are preferred and easier to purchase, the reason behind these results could be the novelty of the goat milk yogurt.

Table 13: Assessment of plain yogurt No. 2 (goat milk yogurt) $n=202$

\begin{tabular}{lllllll}
\hline & \multicolumn{6}{c}{ Characteristics } \\
\cline { 2 - 7 } Value & $\begin{array}{l}\text { Homo- } \\
\text { geneity }\end{array}$ & Smell & $\begin{array}{l}\text { Den- } \\
\text { sity }\end{array}$ & Taste & $\begin{array}{l}\text { Co- } \\
\text { lour }\end{array}$ & $\begin{array}{l}\text { Cream- } \\
\text { iness }\end{array}$ \\
\hline Mean & 7,38 & 7,28 & 7,41 & 6,33 & 8,42 & 7,33 \\
Median & 8,00 & 7,00 & 8,00 & 7 & 9,00 & 7,00 \\
Standard & 2,299 & 2,395 & 2,230 & 2,729 & 1,942 & 1,942 \\
deviation & & & & & & \\
\hline
\end{tabular}

Source: Own research, 2018, 2019.

Our respondents would be willing to pay 0,49 USD and 0,53 USD on an average for 1 cup (150 gr) cow milk and goat milk plain yogurt respectively. Although the real market price of handmade plain cow and goat milk yogurt (150 gr) is roughly 0,36 USD and 0,75USD respectively. It can be stated they were willing to pay higher price for the cow and lower price for the goat milk yogurt. It has to be emphasised again, that goat milk products are not widely consumed in Hungary and consumers are not up-to-date regarding these products, including their price as well.

We asked our respondents how they would consume the tested plain yogurts. They had to rate the following options on a scale 1-5, where 5: the most and 1: the least preferred way of consumption. Results can be seen in Table 14-15. As regards goat milk plain yogurt the means are always slightly lower. The average differences from the medians are always higher. Probably the novelty, or the special taste of the product may cause the more extreme ratings.
Table 14: How would you consume yogurt No. 1 (cow milk yogurt)? $\mathrm{n}=202$

\begin{tabular}{llll}
\hline $\begin{array}{l}\text { Preferred ways of } \\
\text { consumption }\end{array}$ & Mean & Median & $\begin{array}{l}\text { Std. } \\
\text { Deviation }\end{array}$ \\
\hline with fruit & 3,78 & 5 & 1,544 \\
with bakery product & 3,55 & 4 & 1,447 \\
with honey & 2,34 & 2 & 1,624 \\
to salad & 3,42 & 4 & 1,533 \\
to cook with & 2,93 & 3 & 1,590 \\
\hline
\end{tabular}

Source: Own research, 2018, 2019.

Table 15: How would you consume yogurt No. 2 (goat milk yogurt)? $n=202$

\begin{tabular}{llll}
\hline $\begin{array}{l}\text { Preferred ways of } \\
\text { consumption }\end{array}$ & Mean & Median & $\begin{array}{l}\text { Std. } \\
\text { Deviation }\end{array}$ \\
\hline with fruit & 3,15 & 3 & 1,613 \\
with bakery product & 3,14 & 3 & 1,579 \\
with honey & 2,2 & 2 & 1,624 \\
to salad & 3,13 & 3 & 1,565 \\
to cook with & 2,65 & 3 & 1,493 \\
\hline
\end{tabular}

Source: Own research, 2018, 2019.

We can state that the preferred way of consumption is 'with fruit', followed by 'with bakery product', while 'with honey' is the least preferred way of consumption in case of both plain yogurts. It can be stated, that in all cases the mean and median are not quite close to each other. The standard deviation is not so low, thus the data are not so homogenous.

We asked our respondents which fruit they would add to the tested plain yogurts. For the cow yogurt the five most preferred fruits are as follows: apricot, strawberry, raspberry, banana and sour cherry. For the goat yogurt the five most preferred fruits are as follows: apricot, raspberry, banana, strawberry, and pear. We can state that in this term there is not much difference between the tested plain yogurts.

\section{Fruity yogurt}

Respondents had to evaluate fruity cow and goat yogurts, as well, using Likert scale 1-10 (1 is the worst and 10 is the best). Five different characteristics were evaluated by the respondents like homogeneity, density, creaminess, taste and colour. When tasting the yoghurt respondents were asked to fill in a questionnaire. Evaluation of fruity yogurt No. 1 and 2 can be seen in Table 16-17. 
$\underset{\text { AESRA }}{U_{1}}$ Csapo et al.

As regards yogurt No. 1., results of the blind testing (Table 16) show in all cases, that the mean is relatively high, around 7 in case of each characteristics with only slight differences. As regards yogurt No. 2., results of the blind testing (Table 17) show in all cases, that the mean is lower, between 6,06 and 7,45. The median is around the mean. The standard deviation shows in all cases that our data are not homogenous. We can state that perception of goat milk fruity yogurt was only slightly worse than the perception of cow milk fruity yogurt. The perceived characteristics of the yogurts made from goat and cow milk were just slightly different by the respondents. The possible reason behind these results could be the novelty of the goat milk yogurt again.

Table 16: Assessment of fruity yogurt No. 1 (cow milk yogurt) $n=202$

\begin{tabular}{|c|c|c|c|c|c|c|}
\hline \multirow[b]{2}{*}{ Value } & \multicolumn{6}{|c|}{ Characteristics } \\
\hline & $\begin{array}{l}\text { Homoge- } \\
\text { neity }\end{array}$ & Smell & $\begin{array}{l}\text { Den- } \\
\text { sity }\end{array}$ & Taste & $\begin{array}{l}\text { Cream- } \\
\text { iness }\end{array}$ & $\begin{array}{l}\text { Co- } \\
\text { lour }\end{array}$ \\
\hline Mean & 7,08 & 7,14 & 7,11 & 7,29 & 6,91 & 7,92 \\
\hline Median & 7,00 & 7,00 & 7,00 & 8,00 & 7,00 & 8,00 \\
\hline $\begin{array}{l}\text { Standard } \\
\text { deviation }\end{array}$ & 2,416 & 2,522 & 2,355 & 2,613 & 2,413 & 2,205 \\
\hline
\end{tabular}

Source: Own research, 2018, 2019.

Table 17: Assessment of fruity yogurt No. 2 (goat milk yogurt) $\mathrm{n}=202$

\begin{tabular}{lllllll}
\hline \multirow{2}{*}{ Value } & \multicolumn{6}{c}{ Characteristics } \\
& $\begin{array}{l}\text { Homoge- } \\
\text { neity }\end{array}$ & Smell $\begin{array}{c}\text { Den- } \\
\text { sity }\end{array}$ & Taste & $\begin{array}{c}\text { Cream- Co- } \\
\text { iness }\end{array}$ & lour \\
\hline Mean & 6,66 & 6,82 & 6,06 & 6,32 & 6,14 & 7,45 \\
Median & 7,00 & 7,00 & 6,00 & 6,00 & 6,00 & 8,00 \\
$\begin{array}{l}\text { Standard } \\
\text { deviation }\end{array}$ & 2,547 & 2,426 & 2,402 & 2,748 & 2,376 & 2,388 \\
\hline
\end{tabular}

Source: Own research, 2018, 2019.

As regards the price to be paid for fruity yogurt No. 1 and 2, we can state that respondents would be willing to pay 0,47 USD and 0,44 USD for the cow and goat fruity yogurts respectively (for 150 gr). At the same time the real market price of handmade fruity cow and goat milk yogurts (150 gr) is roughly $0,40 \mathrm{USD}$ and $0,84 \mathrm{USD}$ respectively. The price respondents were willing to pay is just slightly lower for the fruity goat yogurt, and the perceived characteristics were also just slightly worse than of the cow fruity yogurt.

\section{CONCLUSION}

Goat milk products are not among the everyday consumed dairy products in Hungary due to several reasons. Among these reasons we have to point out that these products are not easy to find and buy. They can be purchased mainly directly from the farmers or at large supermarkets. The price of these products is relatively high and last but not least they said to have (or at least believed to have) a special "goaty" flavour and smell.

Our empirical research with a sample of 202 in Debrecen region (Eastern part of Hungary), Hungary (Europe) explored the perception of goat cheese regarding its outlook, smell, fatness, taste and colour is almost the same as in case of the tested cow and sheep cheese. The price our respondents would be willing to pay was the highest for the goat cheese. Regarding the preferred way of consumption, it is rather similar for all the three tested cheese (cow, sheep, and goat). They would consume it 'alone' as a cheese plate, 'grilled' or even as an 'ingredient to other meals', such as pizza, soup, etc. Based on these results we can state that the perception of goat cheese was not worse than of the tested cow and sheep cheese. Our respondents were willing to pay the highest price for the goat cheese $(0,82 \mathrm{USD} / 100$ grams). We can suppose that this price is connected to the highest perceived quality, however this price is still much lower than the current market price of goat cheese in Hungary.

The perception of cottage cheese made from goat milk regarding its outlook, smell, fatness, taste and colour is rather similar to the tested cow and sheep cottage cheese. The price our respondents would be willing to pay was the lowest for the goat cottage cheese. Regarding the preferred way of consumption, it is rather similar for the tested cow and goat cottage cheese. The cottage cheese made from sheep milk would be consumed salty by the respondents. Based on these results we can state that the perception of goat cottage cheese was just slightly worse than of the tested cow and sheep cottage cheese. Our respondents were willing to pay the lowest price for the goat cottage cheese $(0,95$ USD/250 grams). We can suppose that this price reflects that goat milk products, as well as their price are rather unfamiliar for our respondents.

The perception of plain and fruity yogurts made from cow and goat milk regarding their homogeneity, 
smell, density, taste, colour, creaminessis rather similar. The perception of goat yogurts was just slightly worse than the cow milk yogurt's. Regarding the price respondents would be willing to pay is also rather similar for the cow and goat yogurts.

We are going to complete this research with an online survey investigating the informedness of respondents on goat milk products (their health benefits, availability, brands) and consumption of such products and frequency of consumption, or refusal of these products with reasoning, affordability of these products, prejudices, etc. Further planned ways of our research is to map the availability, price and origin of goat milk products (Hungarian and imported) in Debrecen, Hungary and to study the economic aspects of goat milk production, as well as the practices and costs of manufacturing goat milk products. After conducting these surveys and analyses we are aiming to contribute with recommendations to the marketing and trade of goat milk products in Hungary.

Based on the results of the blind testing, we can conclude that the perception of goat milk products was rather similar to the tested cow and sheep milk products. Thus, when promoting goat milk products, primarily their nutritional and health benefits, traditional and handmade nature, their tastiness, ways of consumption (recipes) should be emphasised, but their local origin, as well as their high quality should also be pointed out.

\section{REFERENCES}

Albenzo, M., Caroprese, M., Marino, R., Muscio, A., Santillo, A. and Sevi, A. 2006. Characteristics of Garganica goat milk and Cacioricotta cheese. Small Ruminant Research, 64: 35-44.

Baldodiya, V.K. and Sharma, H.O. 2018. Dynamics of Goat Milk Production in Different Agro-Climatic Regions of Rajasthan. Economic Affairs, 63(2): 367-370.

Billion, P. 2003. Milking management. In: Roginski, H., Fuquay, J.W., Fox, P.F. (Eds.), Encyclopaedia of Dairy Sciences. Academic Press, Cornwall, pp. 1243-1253.

Csapó, Zs. and Csapóné R.T. 2019. Kecsketartás, kecsketejtermelés, kecsketej-termékek jelentősége, fogyasztása regionális kitekintéssel. Régiókutatás Szemle, 1: 97-109.

Domonkos, A. and Greiner, E. 2009. A kiskérődzők teje a felnőttek táplálkozásában és a gyógy élelmezésben. In: A tej szerepe a humán táplálkozásban (Szerk.: Kukovics, S), Melánia Kiadó, Budapest, pp. 465-481.
FAO. 2018. http://www.fao.org/dairy-production-products/ production/dairy-animals/small-ruminants/en/Accessed 10 December 2019

Fenyvessy, J. 2009. A kiskérődzők tejének értékes tulajdonságai a fogyasztás és a feldolgozás szempontjából. In: A tej szerepe a humán táplálkozásban. (Ed.: Kukovics, S). Melánia Kiadó. Budapest, pp. 417-424.

Hungarian Chamber of Agriculture. 2017. A kiskérődző ágazat stratégiai fejlesztése 2015. In: A kiskérődző szektor jelene és jövője - A Juh Terméktanács 25 éve tükrében. (Ed.: Kukovics, S), pp. 159-172

Kocsiné Gráf, M. 2011. A szánentáli kecskék életkorának és kondíciójának hatása a tejtermelésre és a szaporaságra. PhD Thesis. Debreceni Egyetem Agrár- és Gazdálkodástudományok Centruma, Állattenyésztési Tudományok Doktori Iskola, pp. 155.

KSH. 2018. https://www.ksh.hu/docs/hun/agrar/html/ tabl1_5_3_4.html Accessed 10 December 2019

KSH. 2019. https://www.ksh.hu/docs/hun/agrar/html/ tabl1_5_1_2.htmlAccessed 10 December 2019

Kukovics, S. 2007a. A kecsketartásban alkalmazott gyephasználat. Magyar Mezőgazdaság, Magyar Juhászat + Kecsketenyésztés, 16(3): 4-7.

Kukovics, S. 2007b. Az anyakecske tartás támogatása. Őstermelő: Gazdálkodók Lapja, 11(4): 92.

Kukovics, S. 2008a. A Magyar juh- és kecskeágazat helyzete és kilátásai. Magyar Mezőgazdaság. Magyar Juhászat + Kecsketenyésztés, 17(3): 2-8.

Kukovics, S. 2008b. Létszám és termelésváltozások az Európai (EU), valamint a magyar juh és kecskeszektorban. In: "A juhtenyésztés jelene és jövője az EU-ban"; (szerk.: Kukovics, S. - Jávor, A.); ISBN 978-963-8030-58-0. Kiadó: Magyar Juhtejgazdasági Egyesület - Debreceni Egyetem Agrár- és Müszaki Tudományok Centruma Herceghalom - Debrecen, pp. 9-29.

Kukovics, S. 2008c. Az EU juh- és kecskeágazata helyzetének felülvizsgálata. Magyar Mezőgazdaság. Magyar Juhászat + Kecsketenyésztés, 17(6): 2-3.

Kukovics, S. and Baranyai, G. 2016. Goat breeds and breeding programmes in Hungary. pp 43-50. In: Sustainable Goat Breeding and Goat Farming an Central and Eastern European Countries. European Regional Conference on Goats 7-13 April 2014 Ed.: Kukovics, S. ISBN 978-92-5109123-4.

Marticsek, J., Előd, R., Székelyhidi, T., Pataki, R. and Belényesi, M. 1999. A kecskeágazat szerepe a nemzeti vidékfejlesztési és környezetgazdálkodási programokban. VI. Debreceni Állattenyésztési Napok. Debrecen, pp. 100-109.

Sunil, V.R., Chandel, B.S. and Makarabbi, G. 2016. Economics of Milk Production in Mandya District of Karnataka. Economic Affairs, 61(4): 659-665.

Szigeti, O. 2004. Kecsketejből készült élelmiszerek táplálkozási előnyei és fogyasztói szokásai. Élelmiszer, Táplálkozás és Marketing, 1(1-2): 1-17. 
$\underset{\text { AESRA }}{W_{1}}$ Csapo et al.

Szigeti, O., Szente, V. and Szakály, Z. 2005. Fogyasztói megítélés a kecsketej termékek piacán. Élelmiszer, Táplálkozás és Marketing, 2(1-2): 29-37.

Szigeti, O., Szente, V., Szűcs, A. and Szendrő, K. 2014. Kecsketej termékek fogyasztói megítélése. Élelmiszer, Táplálkozás és Marketing, 10(2): 29-34.
Yangilar, F. 2013. As a potentially functional food: Goat's milk and products. Journal of Food and Nutrition Research, 1(4): 68-81.

Worldatlas. 2017. https:/www.worldatlas.com/articles/ the-top-goat-milk-producing-countries-in-the-world. htmlAccessed 10 December 2019. 